\title{
CHRONOLOGICAL DATING OF THE DUCHY OF COURLAND'S COLONIAL POLICY
}

\section{Oleg Yevstratyev}

Mg. hist., National Institute for Higher Education (Minsk, Belarus), Department of Historical and Cultural Heritage of Belarus, senior lecturer.

Research theme currently under study: colonial policy of the Duchy of Courland in the 17 th-18th centuries.

Research interests: history of the Baltic region in the early modern period, history of the Duchy of Courland and Semigallia, history of the Grand Duchy of Lithuania, history of European colonialism.

The article considers versions of chronological dating of the history of Courland's colonialism, widespread in historiography. Sources of these versions were found and analysed. It is concluded that an overwhelming majority of assumptions about the time of beginning and end of the history of the Duchy of Courland's colonial policy are imaginary, and rely on questionable secondary historical sources. At the same time, their predominance in relevant historical and popular literature contributes to mythologization of this issue which still takes an important place in the historical memory of the Latvians.

Keywords: Duchy of Courland, colonial policy, chronological dating.

\section{INTRODUCTION}

The colonial policy of the Duchy of Courland and Semigallia (Duchy of Courland or simply Courland in short forms) plays an important role in the historical memory of the Latvian people. The Island of Tobago, where there was a Courlandian settlement in the second half of the 17 th century for a while, is an important place of memory for the Latvians literally from the moment of the emergence of an independent Latvian state after the First World War. Up to now, this faraway Caribbean island 
is perceived as a "promised land" in the historical memory of the Latvians, where their ancestors could gain freedom from serfdom and foreign domination, and also achieve prosperity turning from slaves into slaveholders, from the colonised into colonisers. American researcher Harry Merritt noticed that "with the widespread perception in Latvia that the country was a victim of colonialism under Soviet rule, the existence of a historical 'Latvian' colony helps to mitigate the negative postcolonial feelings of the present". ${ }^{1}$ The colonial episode of Courlandian history had a completely different meaning for German historiography that declared it the first example of a "German colonial feat" capable of justifying the "eternal" German expansionism at the beginning of the Second World War. ${ }^{2}$ Recently, interest in the history of Courland's colonialism arose in some countries whose "ancestors" had an indirect relationship to the Duchy. In 1994, the Polish historian Dariusz Kołodziejczyk wondered, "whether the colony of my vassal is my colony?". 3 Having resolved this "dilemma" in their own favour, some Polish publicists stated that "apart from Poland from sea to sea, there was also one that spread overseas", since "all the territories enriched by the vassals of the Polish-Lithuanian Commonwealth also found themselves in its authorities". ${ }^{4}$ Relying on the same argument, the Belarusian press recently joined the struggle for the Courland's "colonial heritage". 5

As we can see, the "ownerless" history of Courland's colonialism (in contrast to the former powerful metropolises like Portugal, Spain, the Netherlands, England, or France, Courland did not leave behind direct political heirs) became a useful instrument for a number of modern nations to justify their imperial ambitions, or to overcome their "post-colonial syndrome". ${ }^{6}$ At the same time, this episode of Courlandian history is covered with myths like no other. This can be explained to a large extent by the fact that the "colonial legend" for the Latvians and other peoples is based on the historical studies that are now outdated 
or prepared at a low scientific level (by modern standards), and in any case contradict each other. ${ }^{7}$ A thoughtful reader from the first steps faces controversial moments in the history of Courland's colonialism connected with its dating. The aim of this article is to try to identify the lower and upper chronological boundaries in the history of the colonial policy of the Duchy of Courland. This step seems necessary in an effort to clear up the numerous mythological layers of this issue, because the history of any phenomenon begins with its dating.

It should be noted that the colonial policy of the Duchy of Courland will be considered in this article in two senses - broad and narrow. In the first case, it is about traces of participation (or even intentions) of Courland's rulers and their successors in colonial trade (even with colonies of other countries) and diplomatic projects concerning Courlandian overseas possessions. In the second case, it is about Courland's colonies themselves on the mouth of the Gambia River in West Africa and on the Island of Tobago in the Caribbean. In the context of this article, the term "colonialism/colonial policy" includes the activities of a state to establish settlements/colonies on a distant territory with a view to trade and/or planting tropical crops and other goods there. Accordingly, the "colony" is a settlement whose "foreign masters maintain a strong connection with their spatially distant 'homeland' or imperial centre, which claims the exclusive right to 'possess' a colony". 8 The following research methods have been used:

1) determination of the lower and upper chronological boundaries of the history of Courland's colonial policy spread in historiography;

2) identification of the sources of these versions; and

3) verification of the information from these sources on the basis of primary sources available to us. 


\section{LOWER CHRONOLOGICAL BOUNDARY}

The criterion for distinguishing the lower chronological boundary of the phenomenon under consideration is the first traces of Courland's participation in colonial trade and in creation of overseas colonies. The key issue here is the question of when Tobago was purchased and first colonised by the Courlanders. In historiography, two approaches to the dating of this event were formed based on the surviving evidence. We conditionally divided them into "early" and "late".

As for the "early" versions of the beginning of the history of Courland's colonialism, there are no direct sources, only secondary ones created much later than the events described in them happened. Within the framework of this approach, the following dates of the acquisition and first occupation of Tobago by the Courlanders are highlighted:

1610 - James I of England (years of reign 1603-1625) presented his godson, the Courlandian Prince Jacob Kettler (16101681), with Tobago as a christening gift. This version spread in historiography after the corresponding message of the Courlandian diplomat Johann Christoph Praetorius. It is given in his book, first published, apparently, in 1703 in the Hague ${ }^{9}$, or in 1706 in Limbourg ${ }^{10}$, but accessible to us only as a later edition of 1727 published in Groningen in Latin. ${ }^{11}$ The author justifies his conviction about the truth of this version of the acquisition of rights to Tobago by the Courlandian throne with reference to the notice of the English businessman and naval captain John Poyntz (1606 - between 1702 and 1716, or 1630-1712) to the Lords of Trade and Plantations from 18 November $1699 .{ }^{12}$ In 1681, he concluded an agreement with Duke Jacob regarding the re-establishment of the colony on this island. ${ }^{13}$ In his report, the named adventurer promises to inform the Lords "what he knows of the Island of Tobago, from the first grand of King James the first, to James Duke of Courland, until this teime". ${ }^{14}$ 
Additionally, in his memorial to the Lords from 27 November 1699, Captain Poyntz states that "King James and the then Duke of Courland married Ann and Mary, the two Princesses of Denmark, and King James being godfather to the young Prince of Courland, he bore his name, and the Duke his father desired to purchase of King James in the name of his son James, the young Prince, the island of Tobago, to be held and enjoyed under the protection of the Crown of England. Whereon the Earl of Warwick sold his interest in Tobago to Prince James, after Duke of Courland, who thereon sent a squadron of ships and took the possession of Tobago". ${ }^{15}$ As we can see, he does not say directly that this island was presented to Prince Jacob by James I as the christening gift. It seems that Proyntz's information was transformed in Praetorius' work. The Courlandian diplomat wished to link logically the acquisition of rights to Tobago by the ducal house directly with the English throne as the supreme owner of all the overseas possessions of Britain. It must be taken into consideration that his book was created to justify the claims of the under-age Courlandian Prince Friedrich Wilhelm (1692-1711) $)^{16}$ to the said island. Thus, its author was ready to distort his own sources for the sake of his apologetic intention. Praetorius argued, moreover, that in the ducal archives the confirmation of James' I "gift certificate" was kept, which was issued allegedly by Oliver Cromwell in $1652 .{ }^{17} \mathrm{In}$ such a form, this version spread in the 19th-century German historiography and from there transferred to the works of some later researchers. ${ }^{18}$

However, a very convincing criticism of this approach was given already in 1939 by the German historian Otto Heinz Mattiesen. According to his observations, not a single mention of this grant can be found within the richest documentary material for the initial period of the reign of Duke Jacob (1641-1654). In addition, it is obvious that this ruler, impetuously seeking to establish sea trade and acquire colonies, would have started the 
colonisation of Tobago as soon as possible, if he received the island from James I, rather than waiting until 1654 when he suddenly occupied it in fact. After all, if this episode took place, Jacob would have spoken about it constantly and publicly in his usual manner in the course of lengthy disputes over the island which began after 1660, which, however, did not happen. The confirmation of Jacob's rights to Tobago in 1652 also seems impossible. Firstly, the relations between Courland and the Commonwealth of England were still bad in 1652, which is proved by the arrest of two Courlandian ships by England in the same year. Secondly, if Jacob had obtained the rights to Tobago in 1652 or earlier he would not have delayed for another year with its colonisation knowing, moreover, that other powers are laying claim to it. Thirdly, Mattiesen was unable to find the abovementioned confirmation from the Lord Protector in the ducal archives, and also no mention of Tobago is to be found in the negotiating acts with England of that time. ${ }^{19}$

No traces of this document have been found in the English archives as well. ${ }^{20}$ Praetorius probably had in mind the treaty on neutrality and protection between Jacob and Cromwell, concluded in $1654^{21}$, which does not mention Tobago. It was already said about his interest in the artificial deepening of Courland's colonial history until 1610. Poyntz's statement made to the Lords of Trade and Plantations could be explained by similar motives. This adventurer who laid claim to Tobago throughout his life also sought to make the Courlandian throne, with which he once concluded an agreement on the concession to him of lands on this island, one of the first of its legitimate owners. In turn, Poyntz's message on the sale of rights to the island by the Earl of Warwick (Robert Rich (1587-1658) is to be understood under this title) has chronological discrepancies in connection with the mention of James I: the Earl of Warwick was finally recognised as the only patent holder for a number of islands in the West Indies, including Tobago, only in 1639 by 
Charles I of England (years of reign 1625-1649) ${ }^{22}$, i.e. 14 years after the death of James I. After all, at the time of submitting his report, Poyntz was an old man (69 or 93 years old), and his thoughts could be confused. Thus, this version does not correspond to historical reality in any way, but is Poyntz's and Praetorius' fiction invented to serve their selfish interests.

1634 or 1639 - the first Courlandian colonial expedition to Tobago. This hypothesis ascends to the message of the English adventurer and naval commander Major John Scott (16321704) which he left in his manuscript dedicated to the history of this island, among other lands in America (Guiana, Barbados), and written about $1667 .{ }^{23}$ In 1925 , his work, now stored in the British Museum, was published..$^{24}$ Scott says that "the Duke of Corland Anno 1634 sent a ship thither [to Tobago. - O. Ye.] accomodated with Trade to buy it of the Indians, and to take possession on it in his Right. Being before this Sufficiently informed of their inclinations to Trade with the Dutch or English, he purchased it and the Natiues gaue him a cleare possession [...] These people [Courlandian colonists. $-\mathrm{O}$. Ye.] being new hands, as they phrase them in those parts, and haueing noe experienced Planters in their Collonie, and people that came soe farr from the Northward and not any amongst them that knew what was food or Phisick in their proper Seasons, did occassion their mouldring to nothing, 212 men". ${ }^{25}$ This version has gained popularity in historiography. ${ }^{26}$ In the works of some later authors, the existence of that "first" Courlandian colony on Tobago was automatically brought to the next Scott's date associated with the unsuccessful expedition of the English to the island in $1639 .{ }^{27}$ Other researchers questioned the correctness of reading Major's manuscript. According to the Latvian historian Edgars Dunsdorfs, Scott's "1634" can be easily confused with "1639". 28 The scientist himself, however, was inclined to the first variant. He was not embarrassed that Jacob Kettler was not even a duke at the time. He openly wrote that his uncle Friedrich 
(years of reign 1616-1642) could create that colony, but this statement does not agree with the well-known facts about the reign of the latter. ${ }^{29}$ Under the pen of the third authors, "1634" inexplicably turned into " 1637 ". ${ }^{30}$ Compilers of the publication of Scott's manuscript emphasised the impossibility of Courlandian expedition up to $1639 .{ }^{31}$ Following them, a number of researchers cited this year as the date of beginning of the colonial history of the Duchy. ${ }^{32}$ Despite these contradictions, the leading Latvian historian of Courland's colonialism Edgars Andersons (1920-1989) insisted on $1634 .{ }^{33}$ In his view, absence of other reports of this "illegal" enterprise can be explained by Jacob's desire to hide it from his competitors in the colonial arena (English, Dutch, and Spanish). In turn, 212 colonists mentioned above allegedly could be sent to the island for money given to Jacob by the Amsterdam banker Selio Marselis with whom the young Prince established contacts during his educational and diplomatic travel through Europe, which began just in $1634 .^{34}$ However, according to Mattiesen's archival researches, Marselis helped Jacob only in sending a chartered ship from Courland in an uncertain direction ("to the west"), presumably within Europe. ${ }^{35}$ Additional "contemporary" sources cited by Andersons $^{36}$ in no way confirm Scott's message.

The second Courlandian colony on Tobago was dated by the English Major $1642-1650 .{ }^{37}$ Many later historians accepted this dating uncritically and unconditionally (in contrast to doubts about the "first" expedition in the 1630s). For some of them who trusted Scott, it was the second expedition, for others who doubted the truth of latter's information about $1634 / 1639$, it became the first one. ${ }^{38}$ In any case, the contradictory statements of this English adventurer cannot be taken as gospel truth since they are not supported by any other sources, and considering that his manuscript was prepared at least 33 years after the date of the "first" Courlandian expedition to Tobago specified by him. It is unclear what sources exactly did Scott use. ${ }^{39}$ We can 
assume that among them there was the book of the French pastor Charles de Rochefort (1605-1683) about the Antilles first published in 1658 and well-known in those days. It states that "about 30 years ago" 200 colonists from Vlissingen in Zeeland established a settlement on Tobago. ${ }^{40}$ It is likely that Scott who could use the English edition of this book of 1666 and sought to give his own work greater "reliability" by bringing in it more "detailed" information turned "30 years ago" into the middle of 1630s (namely 1634), and 200 colonists from Zeeland into 212 colonists from Courland. He, as the English naval officer who fought then against the Netherlands, could be interested in making the first (after the Spaniards) settlers on Tobago anyone but his enemies. ${ }^{41}$ In the end, it is difficult to imagine that the young Prince Jacob who had not yet taken the throne and who just began to deploy his maritime policy within Europe in the late 1630s suddenly got himself into a colonial adventure, for some inexplicable reasons exactly with Tobago.

1638 - Duke Jacob acquired rights to Tobago from the Earl of Warwick which marked the beginning of Courland's colonial policy. This date is given by the Dutch historian W. R. Menkman without any argumentation or references. ${ }^{42}$ As we have noticed above, the Earl of Warwick became a rightful Tobago proprietor only in 1639 .

1640 or 1642 - the first Courlandian colonial expedition to Tobago. These dates have spread in historiography from Praetorius' book. It is important to note that the text itself mentions "1642"43, and corrections (In textu Corrigenda) to the edition of 1727 - “1640". Courlandian diplomat explains the first date (1642) by reference to the famous work of Alexandre Olivier Exquemelin (ca. 1645-1707), but we cannot find there the corresponding message. ${ }^{44}$ The second date (1640) is not explained in any way. It is likely that Praetorius relied on the opinion of his predecessor in the restitution of the Courlandian colony on Tobago with whom he was in close contact, Baron Karl Johann 
von Blomberg. In 1700, the latter announced to the representative of the Lords of Trade and Plantations, diplomat George Stepney (1663-1707), that Jacob Kettler has first discovered this uninhabited island about 1640, built a fort there, populated it with colonists, and subsequently owned it for many years as an absolute demesne. ${ }^{45}$ Obviously, Blomberg's information cannot be reliable. It was in his own interests to justify his masters' claims to Tobago by "making" them first legitimate owners of the island. Despite the doubtfulness and contradictory nature of Praetorius' information, it formed the basis of a series of studies on the Courland's colonial history: meticulous authors used the version of "1640", the less attentive historians (overwhelming majority) of " 1642 " 46

Middle of the 1640s - Duke Jacob purchased the Island of Tobago from the Earl of Warwick as well as two small islands in the mouth of the Gambia River from chief of the African Barra tribe. One of the first researchers of Courland's colonialism, the German historian Hugo Sewigh, brings this incorrect information without any argumentation. ${ }^{47}$

Years of reign of Charles I of England (1625-1649) - Duke Jacob received Tobago from the named monarch as refund for supplying him during the English Civil War. ${ }^{48}$ As we can see, this "safe" but worthless hypothesis unites and, at the same time, neutralizes all the contradictory versions mentioned above.

The "late" approach to the problem of dating of the first Courlandian colony on Tobago is based on reliable primary sources which are also confirmed by other evidence. It asserts that the first documented Jacob's colonial expedition arrived on Tobago on 20 May 1654. ${ }^{49}$ At the same time, the date of acquisition of the said island by the Courland's ruler remains controversial due to the lack of direct sources on this issue. Some researchers stated that Jacob purchased the rights to Tobago from the Earl of Warwick before $1652^{50}$, or specifically between 1645 and $1647 .{ }^{51}$ However, Mattiesen's point of view seems to be the 
most reasoned one. According to him, a deal between Jacob and the Earl of Warwick who wished to get rid of his useless "property" could be concluded in September 1653. But the Courland's ruler did not pay the agreed amount to the Earl of Warwick. He knew that the latter had no authority to sell the island which was a fief obtained from Charles I who had already passed away by that time. Hence, nobody could dispute this transatlantic possession. At the same time, Jacob got valuable information - Tobago was not occupied by anybody from Europeans. Hereupon he immediately equipped his first colonial expedition there. The fact of "violent annexation" of Earl of Warwick's "property" by the Duke caused the absence of documentation about their "deal" ${ }^{52}$ This version, in contrast to those mentioned above, is consistent with information on the activities of other personalities (in particular, the Duke's agent in London Philipp Freher) as well as with the internal logic of development of Courland's colonialism. ${ }^{53}$

From this, it becomes clear that Jacob established his colony in West Africa earlier than in the West Indies. The date of this event is easily defined by primary sources: Courlandian ships reached the mouth of the Gambia River in late October 1651.54 There, on the St. Andrew's Island (present-day Kunta Kinteh Island), the Courlandian fort was built. In this light, assumptions of some 19th-century historians that Jacob's colony in Gambia was established between 1638 and 1642 seem incorrect. ${ }^{55}$

However, the first traces of overseas activity of the Courlanders are not directly related to the establishing of colonies in Gambia (1651) and on the Island of Tobago (1654):

$1627,1629,1630,1642,1645,1653$ - the first four dates relate to the doubtful episodes discovered by Andersons. These are: the colonial offer of the founder of the Dutch and Swedish West India Companies Willem Usselincx to Duke Friedrich Kettler (1627), the diplomatic activity of the English Ambassador in Warsaw Thomas Roe who could tell the Kettlers about Tobago 
(1629-1630), Courlandian officer Joachim Deniger von Olinda's participation in the military action in Brazil on the Dutch side, he also could tell the Duke about the wealth of the West Indies (1630), Duke Jacob's invitation to Charles I to take part in some kind of dark trade, probably of a colonial nature (1642). However, even if we admit the reality of these hypothetical episodes, they are of little interest since they were of a private and accidental nature and did not affect further Courland's colonial policy. Primary sources found by Andersons in the National Archives of the Netherlands in the Hague and in the collection of documents of the British statesman John Thurloe (1616-1668) are much more worthwhile. They prove the fact of Duke Jacob's participation in the triangular trade between Europe, Guinea, and the West Indies in July 1645 and April 1653. In the first case, it is about the Courlandian ruler's ship "De Hoop" (apparently, it was built specially for him in Dutch Zaandam). Under the Dutch command, this vessel was sent by Jacob from Amsterdam to the Grain Coast (present-day Liberia) to purchase ivory and melegueta pepper for European goods. This cargo was then carried to the West Indies (the ship was seen near the French coast of the Saint Martin Island in July 1645). A load of tropical timber was taken there for the return journey to Europe (apparently, back to Amsterdam). In the second case, we read about the ship "Der Leopard" (it was built most likely in Courland). For Jacob's money, but again under the Dutch command, it was sent from Courland to Amsterdam in April 1653. The vessel was loaded there by Duke's agents with copper ingots and other items for delivery to Guinea where this cargo was sold out, and the empty holds were filled with slaves. Hereupon, slaves were taken to the Martinique Island where a small amount of certain goods was taken for the return journey to Amsterdam. ${ }^{56}$

1643 - negotiations between Courlandian Ambassador Georg von Fircks and the authorities of France and the 
Netherlands about Duke Jacob's participation in the colonial companies of these countries. ${ }^{57}$ As Mattiesen showed persuasively, Jacob began the negotiations on colonial affairs with these countries only in $1646-1647 .{ }^{58}$

1645 - the first Courlandian colonial expedition to Guinea on the ship "Fortuna". This journey, failed subsequently, began in late autumn of 1645. Mattiesen brings this information with references to reliable sources. ${ }^{59}$

1647 - Duke Jacob's negotiations with the Polish King Władysław IV (years of reign 1632-1648). This information is contained in the book of Polish journalist Marek Arpad Kowalski dedicated to the colonial ambitions of the Poles. ${ }^{60}$ This fantastic episode is not based on any sources, and was clearly planned by the author as evidence of the antiquity of the "Polish colonial history", as well as the statement that Courland's ruler conducted colonial negotiations also with the Polish King John II Casimir (years of reign 1648-1668) in $1651 .^{61}$

1649 and 1650 - a number of researchers ${ }^{62}$ considered only these dates mentioned in some primary sources ${ }^{63}$ as reliable time for the beginning of Courland's colonial history.

It should be emphasised that most historians sought to combine uncritically all the versions mentioned above. This caused great confusion in the dating of the colonial history of the Duchy. In addition, this contradictory and unreliable information is actively relayed in numerous cases in non-specialized literature (especially in English) on various aspects of European colonialism in West Africa and the West Indies.

In the light of the foregoing considerations, year 1645 can be considered as the most plausible dating of the beginning of Duchy of Courland's colonial policy. Duke Jacob's participation in the triangular trade as well as sending his first colonial expedition to Guinea can be discovered within this year. In turn, Courlandian settlements at the mouth of the Gambia River and on the Island of Tobago were established no earlier than in 1651 
and 1654, accordingly. These approaches are supported by reliable primary sources, and also are consistent with the events in the history of European colonialism as well as with the internal logic and chronology of the economic and political development of the Duchy of Courland.

\section{UPPER CHRONOLOGICAL BOUNDARY}

The criterion for its distinguishing is the last traces of Courlandian colonial activity. In this respect, things are even worse than with the lower chronological boundary. The "diplomatic" period of Courland's colonial history in the 18th century was overall considered as insignificant, and the rare sources on this topic found by historians have been therefore studied superficially and uncritically. In historiography, there is a common view that Courland's colonial policy continued until the end of the Duchy in 1795 in the form of vain claims to Tobago as well as in the form of appointment of governors there. ${ }^{64}$ This belief dates back to the corresponding reports from the manuscript of the Courlandian Baron Ewald von Klopmann (1734-1804). This "book" is dedicated to the Courlandian episode in the history of Tobago and was written initially in 1795-1796 (its copy also appeared in 1798).

There are at least three copies of this manuscript (made by the author himself), the contents of which are somewhat different. Up to now, only the version of this work from Riga was known to the researchers. It was published with some inaccuracies by the Dutch historian J. Kleyntjens in $1949 .{ }^{65}$ We can read there that Kettlers' successors on the Courlandian throne (Maurice de Saxe (1696-1750) and Ernst Johann von Biron (16901772)) laid claim to Tobago. Later researchers extended the history of Courland's colonialism to the last Duke Peter von Biron (1724-1800). ${ }^{66}$ 
According to Klopmann, Maurice de Saxe who had a residence in the Duchy in 1726-1727 as an "eventual successor" of the ducal throne ${ }^{67}$ (but Klopmann mentions him as a "Duke of Courland and Semigallia"68) conceived to send the colonists to this island, which he regarded as the property of the Courlandian throne, in order to establish new plantations there. He even appointed a governor there - his supporter, the Courlandian nobleman Heinrich Christian von den Brincken (1648-1729). Moreover, Maurice de Saxe hired several people who were to accompany the new governor to Tobago. However, despite the support expected from the kings of Poland and France, nothing out of this undertaking was implemented since the "unexpected Duke" was dethroned by the Russians. ${ }^{69}$ This episode is not supported by any other sources.

Ernst Johann von Biron ruled the Duchy of Courland in 1737-1740 and 1763-1769. According to Klopmann, becoming a Duke he acquired "allodial title" to Tobago from the surviving representatives of the Kettler family for a large sum of money. After that, he appointed him, Baron von Klopmann ${ }^{70}$ who was allegedly Ernst Johann von Biron's Kammerjunker, ambassador to London with the aim of obtaining protection from the English monarch and renewing the commercial and colonial treaty concluded between Duke Jacob and King Charles II in 1664. Six years after Klopmann's stay in London, the British Ambassador in Russia, Sir Charles Hanbury Williams (1708-1759), who obviously sympathised with the Courlandian nobleman, attempted to help him in his task execution by intercession before the British monarch. However, Ernst Johann von Biron's death interrupted the implementation of that plan. ${ }^{71}$

The reliability of the latter fragment is doubtful due to a number of its significant chronological and logical contradictions. Klopmann was born in $1734 .^{72}$ Therefore, he could go to England by Ernst Johann von Biron's order only during the second period of reign of the latter, i.e. between 1763 and 1769 . 
However, Williams mentioned in the work of the Courlandian Baron actually was in Russia as the English Ambassador in 1755-1757, whereupon he died in England in 1759 suffering from insanity. ${ }^{73}$ In turn, Ernst Johann von Biron was at the time in exile, and he clearly could not care about the restitution of Tobago especially under the conditions when even his Courlandian possessions were confiscated. ${ }^{74}$ From Klopmann's autobiography, we can find out that he was really familiar with Williams. This work describes in some detail their joint journey to the United Kingdom through Hamburg during which Klopmann was even appointed personal secretary of the British Ambassador and allowed to conduct his private correspondence. ${ }^{75}$ The information given by the Baron suggests that he was in the company of Williams who suffered from insanity attacks and received resignation due to illness from the autumn of 1757 until the summer of $1758 .{ }^{76}$ But directly from the autobiography written by Klopmann at the age of $66-67^{77}$ and characterised by chronological inconsistency, we can understand that their acquaintance occurred after 1662 when the former English Ambassador was dead already for three years. Apparently, the elderly Baron could get confused with the events having occurred more than forty years before considering that he left Williams before his death and could not have known its date. At the same time, Klopmann reports that Ernst Johann von Biron first contacted him immediately after his return to the ducal throne in 1763 , i.e. four years after Williams' death, and invited him to serve as his son Peter's Kammerjunker - not Ernst Johann's himself as it is clear from Klopmann's manuscript on the history of Tobago. ${ }^{78}$ Thus, the Courlandian Baron began to serve the House of Biron when the said British Ambassador in Russia in no way could help to implement the hypothetical Ernst Johann's colonial plan. After 1763, Klopmann never visited England again. ${ }^{79}$ In addition, according to his autobiography, from 1654 to 1660 , after completing his studies in Jena, he travelled 
through Europe spending two years in London, not six as stated in his manuscript on Tobago. ${ }^{80}$ In the end, the said autobiography does not mention this island and Klopmann's embassy to England concerning its restitution.

At the moment, doubtful information about the colonial efforts of Kettlers' successors on the Courlandian throne is found only in Klopmann's manuscript. As noted above, there are three copies of this "book". We have already considered the content of one of them, the most popular that is stored in Riga. We were able to discover two more versions of this text in the Russian State Archive of Early Acts in Moscow. ${ }^{81}$ They can tell us about Klopmann's motives for preparing his manuscript. The first "Moscow copy" of this work is dated by the author himself in Mitau (present-day Jelgava, former capital city of the Duchy of Courland) on 15 March 1796 and addressed to the Russian Empress Catherine II (years of reign 1762-1796). ${ }^{82}$ In this version, there are no mentions of Klopmann who, according to the manuscript from Riga, was sent to London in connection with Tobago issue by Ernst Johann von Biron. At the same time, it specifies that the latter desired to ask for patronage over this island King George III of the United Kingdom (years of reign 17601820). ${ }^{83}$ This circumstance clearly contradicts the information contained in the manuscript from Riga about the intercession of Ambassador Williams who died, as was said above, in 1759. Eventually, Klopmann brings his story to Peter von Biron (years of reign 1769-1795): at the end of his rule, Courland became part of the Russian Empire (28 March 1795). Further, in the first "Moscow copy" of his work, Klopmann states as follows (without any mention of the "colonial activity" of the last Duke of Courland): "[...] [the Russian Crown. - O. Ye.] received his (Peter von Biron's. - O. Ye.] Courlandian possessions, including the Island of Tobago, by right of inheritance, and as a result of an agreement between his father [Ernst Johann von Biron. $O$. Ye.] and the heirs of the Ducal House of Kettler to whom 
they doubtless belonged. Based on these considerations and the immutable natural and international laws, it would be very easy to prove the justness and indisputability of the sovereign rights of Your Imperial Majesty in Russia to the said Island of Tobago which was legitimately acquired [by the Russian Empress. $O$. Ye.] as an allod of the last Duke of Courland in consequence of his solemn resignation. Deign, Catherine II, legislator and benefactor of millions of people in Your vast Empire, to turn Your gaze one day upon the Island of Tobago, this ancient heritage of the Dukes of Courland!" ${ }^{84}$ The second "Moscow copy" of the Klopmann's manuscript has similar content. It is dated 1 January 1798 in Mitau and addressed to the Russian Emperor Paul I (years of reign 1796-1801). ${ }^{85}$ It is worth to note the author's remark that he sent a copy of his manuscript to Emperor at the own request of the latter. ${ }^{86}$ Apparently, the Russian rulers were really interested in laying claim to the former overseas possession of the House of Kettler. However, it has not been done due to natural reasons (death of Catherine II eight months later after sending of Klopmann's work to her, murder of Paul I in 1801, death of the Courlandian Baron in early $1804^{87}$ ).

Information of the "Moscow copies" of Klopmann's manuscript makes it possible to state confidently that his "book" did not pursue the apologetic goal of justifying the claims of the Dukes from the House of Biron to that distant Caribbean island (for example, Mattiesen and Kleyntjens believed that Klopmann actually travelled to London in connection with Tobago issue by the order of Ernst Johann von Biron ${ }^{88}$ ). This work was written less than a year after the incorporation of the Duchy into the Russian Empire (it can be understood from the last date in the "book" itself - 28 March 1795, and from the date of sending the manuscript to Catherine II - 15 March 1796). Thus, describing the persistent struggle of the Dukes - right up to the last of them, Peter von Biron - for Tobago as their "legitimate allod" Klopmann intended to express his loyalty to the new masters of 
his homeland in person of the Russian emperors who could allegedly acquire that island in addition to the lands of Courland itself.

Klopmann had open access to the ducal archives at that time. This to a large extent contributed to the writing of his research. He probably found there documents relating to the history of Courlandian colonisation of Tobago. ${ }^{89}$ However, this indomitable adventurer (Klopmann's autobiography shows clearly such inclinations in his character) driven by personal ambitions was not afraid to "transform" historical reality. Bringing his story to Kettlers' successors on the ducal throne (Maurice de Saxe and Ernst Johann von Biron) he decided to invent the circumstances of their colonial efforts due to the absence of the authentic sources which could prove that. To this end, Klopmann used the most famous persons and facts: Brincken, the most influential supporter of Maurice de Saxe in Courland, was made by Klopmann "governor" on Tobago; Klopmann "appointed" himself to the position of Ernst Johann von Biron's ambassador to London in order to solve the problem with the island. The Courlandian Baron lived in England for a while, served faithfully the House of Biron for more than 30 years, and was familiar to the British Ambassador Williams. That's why he seemed to be the most suitable person for such a role. Moreover, Ernst Johann von Biron, as Klopmann believed, could purchase the rights to Tobago from the heirs of the Kettler dynasty: he began to implement a similar procedure in regard to the possessions of the former Dukes in Courland itself even before his accession to the ducal throne..$^{90}$ In the end, by Courlandian Baron's good will the Russian emperors became the "legitimate heirs" of Tobago after the last Duke Peter von Biron.

The only reliable document on the Tobago issue from the period of Ernst Johann von Biron's rule contains a request of the late Captain Poyntz's heirs for certified copies of the documents related to the treaty of 1681 between Poyntz and Duke Jacob 
which were stored then in the ducal archives in Mitau. The petitioners represented by the London merchant Atkins feared that the English Crown could provide some third party, not them, with 120000 acres on Tobago received by their ancestor from Jacob in $1681 .{ }^{91}$ On 14 November 1763, this petition was submitted to Ernst Johann von Biron by the merchant from Riga Friedrich Thiringk. It was exactly the year when the United Kingdom, according to the Treaty of Paris between the participants of the Seven Years' War (1756-1763), became the "official" proprietor of Tobago. ${ }^{92}$ Most likely, this circumstance motivated the representatives of the Poyntz family to restore their "rights" to lands on that island.

However, despite the contradictions mentioned above, the authors of special studies on the Courland's colonialism trusted Klopmann completely. Following him, they included absolutely all of the Courland's rulers, beginning with Jacob Kettler and ending with Peter von Biron, in that episode of history of the Duchy. This led to the emergence of a historiographical myth, according to which the colonial policy of the Duchy of Courland was pursued until its incorporation into the Russian Empire in 1795. At the same time, the last traces of Courlandian "colonial activity" dates back to 1731. It is about the attempts of the Duke-in-exile Ferdinand Kettler (1655-1737) to sell Tobago to his nephew Frederick I of Sweden (years of reign 17201751). ${ }^{93}$ The last document on this issue is dated 3 October 1731. This is the response letter of Frederick I to his uncle in which he promised to ponder the proposal about Tobago. However, we could not find any further action on this matter.

After the death of Ferdinand, the last representative of the male branch of the Kettler family, in 1737, the British received legal basis to deny every claim to Tobago that relied on "Courland's rights" to this island. They recognised only the House of Kettler, not the Duchy of Courland or its throne as the former proprietor of Tobago. The opinion of the English writer John 
Fowler from his book about the island of 1774 could be considered as characteristic for that time: "The male line of the house of Kettler, dukes of Courland, becoming extinct in 1737, on the demise of Ferdinand, son to James aforesaid, the fief of this island of course reverted to the crown of Great Britain". ${ }^{4}$ This circumstance clearly characterises the specificity of the colonial policy of the Duchy of Courland as a whole. It was the private initiative of Duke Jacob Kettler and his family heirs. Thus, after the extinction of the male branch of the ducal House of Kettler, the history of the colonial policy of the Duchy of Courland could not continue in any case.

\section{CONCLUSIONS}

The history of the Duchy of Courland's colonial policy, as far as the reliable sources allow us to define, can be dated 16451731. Its following periodization seems the most reasonable from the point of view of the internal content of this phenomenon:

July 1645 - October 1651 / May 1654. The efforts of Duke Jacob to establish overseas settlements that appeared at the mouth of the Gambia River and on the Island of Tobago accordingly.

October 1651 / May 1654 - December 1659. Active period of exploitation of the overseas possessions by Jacob Kettler until his captivity by Swedes on 9 November 1658. Duke was imprisoned until the Treaty of Oliva of 3 May $1660 .{ }^{95}$ By the end of 1659, his colonies were captured by the Dutch (Courlandian fort on Tobago was taken by them on 11 December 1659). ${ }^{96}$ Subsequently, Tobago changed its masters repeatedly until the beginning of the 19th century when the island finally came under the control of the British Crown in consequence of the Napoleonic wars. ${ }^{97}$ The fort on the St. Andrew's Island in Gambia was occupied by the English in March 1661 after the return of the Courlanders there in June 1660 for a short time..$^{98}$ 
May 1660 - January 1698. The unsuccessful attempts of Duke Jacob and his son Friedrich Casimir (years of reign 16821698 , died 22 January 1698) to restore their colonies at the mouth of the Gambia River and on the Island of Tobago, and since the conclusion of the Anglo-Courlandian agreement on 17 November $1664^{99}$ only on Tobago.

March 1698 - October 1731. Diplomatic struggle over Tobago as a part of "Courlandian inheritance". It is about the attempts of the House of Kettler's representatives to lease the island to English merchants, to receive some monetary compensation for it from the British government, or to sell it to Swedish and even Russian monarchs. On 28 March 1698, the Supreme Council of the Duchy issued instructions to Blomberg regarding the defence of Courland's rights to Tobago in England. ${ }^{100} 3$ October 1731 is the date for the aforementioned letter of Frederick I of Sweden to Ferdinand Kettler about the offer to purchase Tobago - this is the last document known to us from the history of the Duchy of Courland's colonial policy.

In our opinion, the possessions of the House of Kettler in Norway were also part of its "colonial empire". ${ }^{101}$ This includes the harbour on the Island of Flekkerøy which served as a base for Courlandian ships on their transatlantic way since 1651 until the loss of Jacob's settlements in Gambia and on Tobago, and iron mines on the territory of the current municipality of Eidsvoll near Oslo rented from the Danish crown from 1662 to 1688 .

At the same time, the abovementioned mythological eclecticism continues to dominate in the public historical literature as well as in the media. With their help, these distorted views are transmitted to the general public. ${ }^{102}$ 


\section{REFERENCES AND NOTES}

1 Harry C. Merritt (2010). The colony of the colonized: the Duchy of Courland's Tobago colony and contemporary Latvian national identity. $\mathrm{Na}$ tionalities Papers, 38 (4), p. 492. See also Imbi Sooman, Jesma McFarlane, Valdis Tēraudkalns, Stefan Donecker (2013). From the Port of Ventspils to Great Courland Bay: The Couronian Colony on Tobago in Past and Present. Journal of Baltic Studies, 44 (4), pp. 503-526.

2 Otto Heinz Mattiesen (1940). Die Kolonial- und Überseepolitik der kurländischen Herzöge im 17. und 18. Jahrhundert. Stuttgart: W. Kohlhammer, p. XXXV, XXXIX, XLI.

3 Dariusz Kołodziejczyk (1994). Czy Rzeczpospolita miała kolonie w Afryce i Ameryce? Czyli czy kolonia mojego wasala jest moją kolonią? [Did the Polish-Lithuanian Commonwealth have colonies in Africa and America? Or whether the colony of my vassal is my colony?]. Available at: http://niniwa22. cba.pl/kolodziejczyk_kolonie_w_afryce.htm (accessed 07.01.2018).

4 Antoni Olbrychski (2014). Tobago: zamorskie kresy Rzeczypospolitej [Tobago: the overseas borderlands of the Polish-Lithuanian Commonwealth]. Available at: http://histmag.org/Tobago-zamorskie-kresy-Rzeczpospolitej-9488 (accessed 07.01.2018).

5 Aleksandr Pogorelyi. S privetom iz Afriki. V XVII veke u VKL byli zamorskie kolonii. Argumenty i Fakty, 15.01.2014, p. 32, also available at: http:// www.aif.by/timefree/history/item/26645-vkl.html (accessed 07.01.2018); Pavel Dobrovol'skii (2017). V Afrike i Amerike. Kakimi zamorskimi koloniiami vladela Rech' Pospolitaia i kto ikh otobral. Available at: https://news. tut.by/culture/535100.html (accessed 07.01.2018); Kariby, Afrika i rom. Istoriia kolonii VKL v XVII-om veke. Available at: http://1863x.com/vklkolonii/ (accessed 07.01.2018).

6 For details, see O[leg] I[gorevich] Yevstratyev (2015). Kolonial'naia politika Kurliandskogo gertsogstva $\mathrm{v}$ istoricheskoi pamiati narodov Vostochnoi Evropy i Pribaltiki. In: I[gor'] V[ladimirovich] Titovich et al. (eds.). "Sotsial'no-gumanitarnye znaniia": materialy XII. Respublikanskoi nauchnoi konferentsii molodykh uchenykh i aspirantov. Minsk: Respublikanskii institut vysshei shkoly, pp. 42-49.

7 For details on the historiography of this issue, see O[leg] I[gorevich] Yevstratyev (2015). Kolonialnaia politika Kurliandskogo gertsogstva v pribaltiisko-nemetskoi istoriografii vtoroi poloviny XIX veka. In: I[rina] I[vanovna] Kalacheva et al. (eds.). "Istoriia i kul'tura na styke epokh i tsivilizatsii: istoriko-kul'turnoe nasledie kak resurs i rezul'tat razvitiia obshchestva": materialy Mezhdunarodnoi nauchno-prakticheskoi konferentsii, posviashchennoi 250-letiiu M. K. Oginskogo. Minsk: Belnauchkniga, pp. 69-73; A[leh] I[haravich] Yeustratsyeu (2016). "Latviešu kolonisti” vs. "Erster deutsche 
Kolonialversuch": latyshskaia i pribaltiisko-nemetskaya istoriografiia kurliandskogo kolonializma v mezhvoennyi period (sravnitel'nyi analiz). Nauchnye trudy Respublikanskogo instituta vysshei shkoly. Istoricheskie i psikhologo-pedagogicheskie nauki, 16 (1), pp. 96-106; A[leh] I[haravich] Yeustratsyeu (2017). Poslevoennaia istoriografiia kurliandskogo kolonializma. Nauchnye trudy Respublikanskogo instituta vysshei shkoly. Istoricheskie i psikhologo-pedagogicheskie nauki, 17 (1), pp. 78-86.

8 Jürgen Osterhammel, Jan C. Jansen (2012). Kolonialismus. Geschichte, Formen, Folgen. München: C. H. Beck, p. 16.

9 Johann Friedrich von Recke, Karl Eduard Napiersky (eds.) (1831). Praetorius (Johann Christoph). In: Allgemeines Schriftsteller- und GelehrtenLexikon der Provinzen Livland, Esthland und Kurland. Vol. 3, Mitau: Johann Friedrich Steffenhagen und Sohn, pp. 440-442, here p. 441.

10 Mattiesen. Die Kolonial- und Überseepolitik der kurländischen Herzöge, p. XXXVI.

11 J[ohann] C[hristoph] P[raetorius] (1727). Tobago / Insulae Caraibicae / in / America / sitae / fatum [...]. Groningae: Apud Jacobum Sipkes, Caput I, $\$$ III, pp. 20-21: "Is â Serenissimo ac Potentissimo M. B. Rege Jacobo I. Jacobo Duci Curlandiae, cui primùm nato \& sacro baptismatis fonte initiando fidei sponsor extiterat, arrabonem quasi amoris, praefatam Tobago donatam \& abs hoc primam illi impositam fuisse coloniam mihi memoravit. Hanc in Curlandia etiam vigere sententiam saepissimè percepi. Etsi igitur nesciam, utrum tale donationis instrumentum in Archivo Ducali reperiatur nec ne, sequentes tamen satisfacere videntur circumstantiae".

12 All the exact dates in this article are in the New Style.

13 For details about him and his deal with the House of Kettler, see Sir John Maclean (1886). An historical and genealogical Memoir of the Family of Poyntz. Part II, Exeter: William Pollard \& Co., pp. 139-146, 156, 189-190, 198; Mattiesen. Die Kolonial- und Überseepolitik der kurländischen Herzöge, pp. 720-750; Edgars Andersons (1970). Senie kurzemnieki Amerikā un Tobāgo kolonizācija. Stockholm: Stockholms Södra Tryckeri for Daugava, pp. 244-250.

14 In Praetorius' book, we can read follows about the Poyntz's message (Caput II, $\$$ III, pp. 20-21): "Sed Pointzii navis quondam Anglicae praefecti magis arrident dictata [...] Commerciorum in Anglia Consiliarios vel Commissarios hujus non fuisse ignaros donationis vel exinde intelligi potest, quod Pointzio demandarint, ut illos de Tobago insulae statu \& vicissitudine, a primâ Regis Jacobi I. Jacobo Duci Curlandiae impertitâ Concessione NB. ad hoc usque tempus, quam primûm posset, instrueret, sicuti ex horum mandatorum exemplis Anglicis, quae Londini nactus sum \& heic (g) subjunxi, apparet [...] (g) [...] 1699. (2) Capt. Poyntz is desired to inform the board what he knows of the Island of Tobago, from the first 
grand of King James the first, to James Duke of Courland, until this teime, (as particularly as he kan) when any change therin happened. Hoc mandatum Pointzio, prout desiderarat, scripto expressum, die 8. Novemb. datum fuit".

15 Cecil Headlam (ed.) (1908). Calendar of State Papers, Colonial Series, America and West Indies. Preserved in the Public Record Office. Vol. 17 (1699), London, № 973, p. 528.

16 Dedication to him in Praetorius' book is dated 20 September 1705 in the Hague.

17 In his brief handwritten essay on the "Courlandian" history of Tobago written around 14 October 1701, Praetorius states: "Capt.: Poyntz, in seinen auf der Commitè begehren gethanen bericht, [...] vermeinet daß solches von König Jacobo den ersten, an Ihro Hochfürstl. durchl. hertzog Jacobo hochseel. andenkens sey cediret worden (Uber dieß ist noch eine Confirmation von Cromweld von Ao. 1652. in dem hochfürstl. Archiv vorhanden)" (Johann Christoph Praetorius' draft on the history of Courland's rights to the Island of Tobago [in German], ca. 1701. Prussian Privy State Archives (Geheimes Staatsarchiv Preußischer Kulturbesitz, Berlin, hereinafter: GStA PK), I. HA - Rep. 9 Polen - 7e1. Acta der Insel Tabago (16641721), pp. 118-121, here p. 119).

Ludwig Albrecht Gebhardi (1789). Geschichte des Herzogthums Kurland und Semgallen [...]. Halle: Johann Jacob Gebauer, 1789, p. 66, footnote t; Karl Wilhelm Cruse (1833). Curland unter den Herzögen. Vol. 1, Mitau: G. A. Reyher, p. 147; A[lexander] von Richter (1858). Geschichte der dem russischen Kaiserthum einverleibten deutschen Ostseeprovinzen bis zur Zeit ihrer Vereinigung mit demselben. Theil II. Die Ostseelande in ihrer provinziellen Entwickelung. III. Band. Kurland unter den Herzögen. 1562-1795. Riga: Nicolai Kymmel, p. 66; V[incent] T. Harlow (ed.) (1925). Colonising Expeditions to the West Indies and Guiana, 1623-1667. London: Bedford Press for the Hakluyt Society (Works issued by The Hakluyt Society. Second series, No. LVI), pp. LIX, LXI; Lady Bella Southorn (1952). The Gambia. The Story of the Groundnut Colony. London: George Allen \& Unwin Ltd., p. 76; John M. Gray (1966). A History of the Gambia. London: Frank Cass \& Co. Ltd., p. 39; Cornelis Ch. Goslinga (1971). The Dutch in the Caribbean and on the Wild Coast 1580-1680. Assen: Van Gorcum \& Comp. N. V., p. 434; Carlton Robert Ottley (1973). The Story of Tobago. Robinson Crusoe's Island in the Caribbean. Thetford: Lowe \& Brydone for Longman Caribbean, p. 13 (this author mixed up James I with Charles I, and 1610 with 1641); Christoph Rella (2008). "Im Anfang war das Fort". Europäische Fortifizierungspolitik in Guinea und Westindien 1415-1815. Expansion Fortifikation - Kolonisation. Ph. D. Wien: Universität Wien, p. 208; Dmitrii Kopelev (2015). Ostrov Tobago v fokuse geopolitiki XVII-XVIII vekov: 
Kurliandskaia imperiia i Petr I. In: V[alerii] P[avlovich] Solomin et al. (eds.). IV Mezhdunarodnaia nauchno-prakticheskaia konferenciia "Prirodnoe i kul'turnoe nasledie: mezhdisciplinarnye issledovaniia, sohranenie i razvitie": kollektivnaia monografiia. Saint Petersburg: Izd-vo RGPU im. A. I. Gertsena, pp. 96-106, here p. 100.

19 Otto Heinz Mattiesen (1939). Die Kolonial- und Überseepolitik Herzog Jakobs von Kurland 1640-1660. Inaugural-Dissertation. Stuttgart: W. Kohlhammer, p. 434.

20 See William Noël Sainsbury (ed.) (1860). Calendar of State Papers, Colonial Series, 1574-1660. Preserved in the State Paper Department of Her Majesty's Public Record Office. Vol. 1, London, p. 370-396.

21 For the text of this document, see Aleksandrs V. Berkis (2009). Kurzemes hercoga Jēkaba drošības politika no 1638. līdz 1658. gadam. Militārais Apskats, 3/4, pp. 61-77, here pp. 66-67.

22 Mattiesen. Die Kolonial- und Überseepolitik der kurländischen Herzöge, pp. 428-429.

23 George Edmundson (1901). The Dutch in Western Guiana. English Historical Review, XVI (64), pp. 640-675, here p. 640, footnote 1.

24 John Scott (n. d.). The Discription of Tobago. In: V[incent] T. Harlow (ed.). Colonising Expeditions to the West Indies and Guiana, 1623-1667. London: Bedford Press for the Hakluyt Society, pp. 114-119.

25 Ibid., pp. 114-115.

26 One of the first researchers who insisted on the reliability of Scott's information was the British historian George Edmundson (1848-1930). In his article of 1901, he sought to prove Scott's truth comparing messages of the latter with other sources. In fact, however, he confined himself to much later works by Praetorius (1727), anonymous English author (1750) who does not give any dates of the "first" Courlandian activity on Tobago until 1654, and German historian Karl Wilhelm Cruse (1833). After all, Edmundson's "criticism" turned into adapting the messages of these later authors to Scott's information which were accepted by him for a priori truth. On the quality and depth of Edmundson's study - in those parts of it that concern the "first" Courland's attempts to colonise Tobago in the 1630s-1640s (according to Scott) - speak eloquently the facts that he believes in the version of the christening gift from James I, and does not know what the abbreviation "J. C. P." means, by which Praetorius signed his book (see Edmundson. The Dutch in Western Guiana, pp. 640-647).

27 Harlow. Colonising Expeditions, p. LIX; C. K. Kesler (1929). Tobago. Een vergeten Nederlandsche Kolonie. De West-Indische Gids, 10, pp. 527-534, here pp. 530-531; W. R. Menkman (1939). Stukken betrekkelijk het eiland Tobago 1664-1684-1698. Rotterdamsch Jaarboekje, 4 (7), pp. 80-93, here p. 82; W. R. Menkman (1939). Tobago. Een bijdrage tot de geschiedenis der 
Nederlandsche kolonisatie in tropisch Amerika. Part 2. De West-Indische Gids, 21, pp. 305-314, here p. 307; Goslinga. The Dutch in the Caribbean, p. 437.

28 In this way, for example, this manuscript was read by Edmundson (Edmundson. The Dutch in Western Guiana, p. 642).

Edgars Dunsdorfs (1962). Latvijas vēsture 1600-1710. Uppsala: Appelbergs Boktryckeri AB for Daugava, p. 67, footnote 12. Similar views are shared by other historians (Alfred Bilmanis (1951). A History of Latvia. Princeton: Princeton University Press, p. 189; Goslinga. The Dutch in the Caribbean, p. 437). Regarding the reign of Friedrich Kettler in Courland see Volker Keller (2005). Herzog Friedrich von Kurland (1569-1642). Verfassungs-, Nachfolge- und Neutralitätspolitik. Marburg: Verlag Herder-Institut (Materialien und Studien zur Ostmitteleuropa-Forschung, 11).

30 Adam Anderson (1764). An Historical and Chronological Deduction of the Origin of Commerce, From the Earliest Accounts to the present Time [...]. Vol. 2, London: Printed for A. Millar et al., p. 62; Sir Alan C. Burns (1965). History of the British West Indies. London: Allen \& Unwin, p. 127; Goslinga. The Dutch in the Caribbean, p. 437; Kopelev. Ostrov Tobago, p. 100.

31 They noticed that in 1634 the colonisation of Tobago was undertaken by Jan de Moor from Zeeland, and not by the Courlanders (Scott. The Discription of Tobago, p. 115, footnote 1; see also Edmundson. The Dutch in Western Guiana, p. 643).

32 Karin Jekabson-Lemanis (2000). Balts in the Caribbean: The Duchy of Courland's attempts to colonize Tobago Island, 1638 to 1654 . Caribbean Quarterly, 46 (2), pp. 25-44, here pp. 25, 31-32; Rella. “Im Anfang war das Fort”, pp. 166, 208.

33 It should be noted that the emigrant Latvian historians who studied Courland's colonialism after the Second World War (Edgars Andersons, Aleksandrs Valdonis Berkis, Karin Jekabson-Lemanis) are united by the desire to romanticise this episode of the history of the Duchy. They not only tried to find any arguments for deepening this phenomenon to the 1630 s, but also "discovered" Latvians on the Courlandian ships and in the Tobago colony. However, all this cannot be proved on the basis of reliable documentary sources (for details, see O[leg] I[gorevich] Yevstratyev (2017). Kolonial'naia “imperiia” na pogranich'e Evropy: geterogennyi kharakter kolonial'noi politiki gertsogstva Kurliandiia i Semigaliia v XVIIXVIII vekakh. In: V[ladimir] A[leksandrovich] Ganskii et al. (eds.). "Problemy istorii $i$ kul'tury pogranich'ia: gumanotarnoie znaniie i vyzovy vremeni": materialy Mezhdunarodnoi nauchnoi konferentsii, posviashchennoi 200-letiiu I. E. Khrapovitskogo (Verkhnedvinsk, Vitebskaiia oblast', Belarus'). Minsk: Belnauchkniga, pp. 95-103). Obviously, this circumstance can be explained by the excess of patriotic intentions in the scientific activity of these researchers. 
34 Edgar Anderson (1961). Die ersten kurländischen Expeditionen nach Westindien im 17. Jahrhundert. Baltische Hefte, 8 (1), pp. 13-35, here pp. 15-17.

35 Mattiesen. Die Kolonial- und Überseepolitik der kurländischen Herzöge, p. 52.

36 Namely, the work by John Fowler of 1774 in which he talks about the Courlandian expedition "several years later" after 1632 (John Fowler (1774). A Summary Account of the Present Flourishing State of the Respectable Colony of Tobago, in the British West Indies. London: Printed for A. Grant, p. 8), and an expanded edition of the famous book by Alexandre Olivier Exquemelin, published in 1684, in which he does not give any exact dates and even chronological reference points for dating the first Courlandian expedition to Tobago ([Alexandre] [Olivier] Esquemeling (16841685). The Buccaneers of America [...]. Revised and edited by William Swan Stallybrass, Introductory Essay by Andrew Lang. London: George Routledge \& Son Ltd., New York: E. P. Dutton \& Co., p. 249). Inappropriate references to Exquemelin are also given by other authors (Goslinga. The Dutch in the Caribbean, p. 438).

37 This settlement was allegedly established in the name of Courland's ruler by the Zeelanders led by the Dutch-Brazilian Captain Cornelius Caroon who arrived on Tobago with 310 colonists in 1642. After 8 years, the survivors were banished from the island by the Caribs (Scott. The Discription of Tobago, pp. 115-116, footnote 1). Andersons, trying to prove the veracity of this message, relied on a very controversial biography of the said Dutch adventurer. At the same time, the Latvian historian noted that this Scott's message is not confirmed by Courlandian sources, but only by documents from the Dutch and English archives which, as can be seen from their content (cited by Andersons), have nothing to do with the imaginary Caroon's expedition to Tobago in the interests of Duke Jacob in 1642. We can only learn from them that Caroon was on this island around 1650, whereupon in the second half of the 1650s, after the actual establishing of the Courlandian colony on Tobago, he laid claim to its southwestern part (Anderson. Die ersten kurländischen Expeditionen, pp. 18-22; see also Edmundson. The Dutch in Western Guiana, p. 651). According to the document first discovered by Dr. Mārīte Jakovḷeva in the Latvian State Historical Archives in Riga, Caroon actually was on Tobago as a Courlandian governor for a while about 1657 after Willem Mollens Jr., the founder of the Courland colony on Tobago, left the island (we were able to see the photocopy of this document at the exhibition organised by Dr. Jakovleva (see Kurzemes un Zemgales hercogs Jēkabs (1610-1681) un viņa laikmets. Talsu novada muzejs. Available at: https://www.talsumuzejs.lv/kurzemes-un-zemgaleshercogs-jekabs-1610-1681-un-vina-laikmets/ (accessed 07.01.2018)) - 
№ 10 of the part of the exhibition on Courland's colonial policy, "Uz Tobāgo nosūtīto kugiu saraksts. Ap 1661./1662. g. Autors nezināms”: "[...] 2. Caron hat nach Mollens daß Gouvernement eine Weile gehabt [...]"). Obviously, after this Dutch-Brazilian adventurer began to claim lands on Tobago. To justify his imaginary "rights" he came up with a story about his colonial expedition to the island in the interest of the Duke of Courland allegedly held as early as 1642, which he could share with Scott, as will be discussed below. It is noteworthy that this doubtful episode of Caroon's biography is propagated to the general reader through popular Internet resources (Cornelius Caroon (From Wikipedia, the free encyclopedia). Available at: https://en.wikipedia.org/wiki/Cornelius_Caroon (accessed 07.01.2018)).

38 Kesler. Tobago, pp. 531-532; Menkman. Tobago. Part 2, p. 308; Anderson. Die ersten kurländischen Expeditionen, pp. 18-22; Goslinga. The Dutch in the Caribbean, pp. 438-439; Marijke Ballintijn (1971). Nieuw-Walcheren: voormaels een woest eijlandt. Zeeuws Tijdschrift, 21 (5), pp. 141-152, here pp. 146-147; Ottley. The Story of Tobago, p. 13; Jekabson-Lemanis. Balts in the Caribbean, pp. 32-40; Rella. "Im Anfang war das Fort", p. 208; Kopelev. Ostrov Tobago, p. 100.

39 Author himself noted that his work was written on the basis of secondary sources (Edmundson. The Dutch in Western Guiana, p. 641).

40 We used the German edition of 1668 ([Charles] de Rochefort (1668). Historische Beschreibung Der Antillen Inseln in America gelegen [...]. Translation by Wilhelm Serlin. Franckfurt: Wilhelm Serlin, p. 26).

41 The Courlanders were suitable for this role. Not long before Scott had written his manuscript, namely in 1659, their colony on Tobago was captured by the Zeelanders, the enemies of the English, and in 1664 the English monarch recognised Duke Jacob as the sole legitimate proprietor of the island. For the same reason, the English Major could "make" Caroon mentioned above the "founder" of the second Courlandian colony on Tobago. It is likely that Scott was personally acquainted with the Dutch Captain, because at the same time (1666) they could be in the same place, namely in Guyana, between two rivers of Pomeroon and Essequibo (Edmundson. The Dutch in Western Guiana, p. 641; Lilian T. Mowrer (1960). The indomitable John Scott: Citizen of Long Island, 1632-1704. New York: Farrar, Straus and Cudahy, pp. 174, 176, 183; Anderson. Die ersten kurländischen Expeditionen, p. 21). Having adventurous inclinations, the English Major obviously felt sympathy for the Dutch swindler whom he described as the "Gentleman of good Conduct" (Scott. The Description of Tobago, p. 116). On the contrary, Caroon was considered as "notorious criminal" in his homeland (Anderson. Die ersten kurländischen Expeditionen, p. 20). The latter could have personally shared with Scott a fictional story about his 
"Courlandian" expedition to Tobago in 1642 to substantiate his claims to the lands on this island before an influential English commander. This is especially true since Duke Jacob was granted with this possession from the English Crown at the time. In this regard, it is difficult to agree with Edmundson's opinion that Scott had no political intentions in interpreting actual and imaginary events around the lands in America described by him (Edmundson. The Dutch in Western Guiana, p. 642). Menkman. Tobago. Part 2, p. 308. $\mathrm{P}$ [raetorius]. Tobago, Caput II, $\$$ IV, p. 23.

Esquemeling. The Buccaneers of America, p. 249. This date could be given by Praetorius who wanted (consciously or not) to link the first appearance of the Courlanders on Tobago with the year of Jacob's accession to the throne (1642).

45 Report from Wilhelm von Pettau, Brandenburg's ambassador to London, to Elector Frederick III [in German], 21.06.1700. GStA PK, Ibid., pp. 99100. v, here p. 99: "In der mit dem von Stepney gehaltenen unterredung hat der freÿherr von Blumberg zu behauptung des rechts, so die Hertzoge von Curlandt auff die Insul Tobago haben, folgendes beÿgebracht: Wie nemlich der Hertzog Jacob ungefehr Anno 1640. sothane, damahlen unbewohnte Insul Zuerst decouvirt, darinn ein Fort, so Er nach Seinem Nahmen benennet, erbauet, mit einwohnern und einer Garnison besetzet, und alß Dominus absolutus viele Jahre ohne einige dependence beseßen habe [...]". Praetorius was aware of Blomberg's opinion: "[...] der Herr Baron blumberg ist, laut des was Er an den Doctor Connor in seiner history of Poland Vol. 2. pag. 106. communiciret, der Meinung, ob hätte es Ihro hochfürstl. durchl. alß ein derelictum oder wüstes Eyland Jure Gentium eingenohmen" (Johann Christoph Praetorius' draft on the history of Courland's rights to the Island of Tobago [in German], ca. 1701. GStA PK, Ibid., pp. 118-121, here p. 119).

46 Gebhardi. Geschichte des Herzogthums Kurland, p. 66, footnote t; Henry Iles Woodcock (1867). A History of Tobago. Ayr: Smith and Grant, p. 24; Edmundson. The Dutch in Western Guiana, p. 644; J[ānis] Juškevičs (1931). Hercoga Jēkaba laikmets Kurzemè. Rìga: Valstpapīru spiestuves izdevums, p. 231; Anderson. Die ersten kurländischen Expeditionen, p. 18. $47 \mathrm{H}$ [ugo] Sewigh (1872). Eine kurländische Colonie. Baltische Monatsschrift, 21, pp. 1-40, here p. 8. See also August Seraphim (1913). Mißlungene Seefahrten nach Westindien. In: Aus vier Jahrhunderten. Gesammelte Aufsätze zur baltischen Geschichte von Ernst und August Seraphim. Reval: Franz Kluge, pp. 51-79, here p. 54.

48 Gebhardi. Geschichte des Herzogthums Kurland, p. 65; Ewald von Klopmann (n. d.). Abrégé de l'Histoire de Tabago. In: J[ean Chrétien Joseph] Kleyntjens S. J. (1949). De koerlandse kolonisatiepogingen op Tobago. 
West-Indische Gids, 30, pp. 197-216, here p. 198; Cruse. Curland unter den Herzögen, p. 147; Juškevičs. Hercoga Jēkaba laikmets Kurzemē, p. 231; Ž[anis] Bundurs (1992). Senās latvju kolonijas Gambija Tabago. Rīga: Lauku Dzive, p. 17; Kopelev. Ostrov Tobago, p. 100.

49 Klopmann. Abrégé de l'Histoire de Tabago. West-Indische Gids, p. 198 (see also Ewald von Klopmann's essay on the history of the Island of Tobago [in French], 15.03.1796, 01.01.1798. Russian State Archive of Early Acts (Rossiiskii gosudarstvennyi arkhiv drevnikh aktov, Moscow, hereinafter: RGADA), 11-1-570, pp. 3, 28. v); Walter Eckert (1927). Kurland unter dem Einfluss des Merkantilismus. Ein Beitrag zur Staats- und Wirtschaftspolitik Herzog Jakobs von Kurland (1642-1682). Riga: G. Löffler, p. 183; Juškevičs. Hercoga Jēkaba laikmets Kurzemē, p. 234; Mattiesen. Die Kolonial- und Überseepolitik der kurländischen Herzöge, pp. 435, 443, 453.

50 Eckert. Kurland unter dem Einfluss des Merkantilismus, p. 183.

51 Anderson. Die ersten kurländischen Expeditionen, pp. 27-29. The version of the Latvian historian seems very doubtful since in 1647 the Earl of Warwick concluded a contract with a group of English merchants for the sale of this island (Mattiesen. Die Kolonial- und Überseepolitik der kurländischen Herzöge, pp. 429, 439). Andersons explained it by the fact that Duke Jacob deferred payment, but in that case it is unclear why he delayed the colonisation of such a desired island.

52 The only document that can relate to this episode we were able to find in the Latvian State Historical Archives in Riga (Anonīms apcerējums par Tobago salas kolonizācijas ekonomiskajām priekšrocībām. 17. gs. [in German]. Latvijas Nacionālais arhīvs - Latvijas Valsts vēstures arhìvs (Rīga, hereinafter: LNA-LVVA), 554-3-387). This is an anonymous and undated German-language 17th-century description of the Island of Tobago. Apparently, this document is a German translation of the Earl of Warwick's letter, in which he assured Duke Jacob of the benefits of the acquisition of Tobago. This can be indirectly indicated by the fact of the great similarity of this document with the contract of 1647 between the Earl of Warwick and the London merchants. Perhaps, this letter was accompanied by a map depicting Tobago, made on donkey skin (Mattiesen. Die Kolonial- und Überseepolitik der kurländischen Herzöge, pp. 470, Karte A).

53 Mattiesen. Die Kolonial- und Überseepolitik der kurländischen Herzöge, pp. 438-445.

54 Heinrich Diederichs (1890). Herzog Jacobs von Kurland Kolonien an der Westküste von Afrika. Mitau: J. F. Steffenhagen und Sohn (Festschrift der kurländischen Gesellschaft für Literatur und Kunst zur Feier ihres 75-jährigen Bestehens), pp. 19-21; Mattiesen. Die Kolonial- und Überseepolitik der kurländischen Herzöge, pp. 118-130.

55 Cruse. Curland unter den Herzögen, p. 146; Richter. Geschichte, p. 66. 
56 Anderson. Die ersten kurländischen Expeditionen, pp. 14-15, 23-25. See also Edgar Anderson (1959). The Couronians and The West Indies. The First Settlements. Caribbean Quarterly, 5 (4), pp. 264-271; Edgars Andersons (1963). Pirmie Kurzemnieki sakari ar Rietumindijas salam. In: Jānis Siliņš (ed.). Rakstu Krājums II. New York: Latviešu Humānitāro Zinātṇu Asociācija, pp. 26-61; Andersons. Senie kurzemnieki Amerikā un Tobāgo kolonizācija, pp. 73-99; Edgars Andersons (1970). Tur plìvoja Kurzemes karogi. Brooklyn (New York): Grāmatu draugs, pp. 20-22. At the same time, the arguments of this historian that Duke Jacob could participate in the "triangular trade" even before 1640 or in 1642 are refuted by his own sources (Anderson. Die ersten kurländischen Expeditionen, p. 22): archival documents that allegedly prove participation of this ruler in the slave trade before 1640 are devoted in fact to the failed expedition of the Courlandian ship "Fortuna" to Guinea in 1645 (Mattiesen. Die Kolonial- und Überseepolitik der kurländischen Herzöge, pp. 60-61); two ships with a load of salt which entered the Baltic Sea through the Sound from the West Indies in 1642 were Swedish, not Courlandian, and sailed obviously to Sweden, not to Courland (Nina Ellinger Bang (1922). Tabeller over skibsfart og varetransport gennem Øresund 1497-1660. Vol. 2A, København: Gyldendalske Boghandel, Nordisk Forlag, Leipzig: Otto Harrassowitz, p. 468; Nina Ellinger Bang, Knud Korst (1933). Tabeller over skibsfart og varetransport gennem Øresund 1497-1660. Vol. 2B, København: Gyldendalske Boghandel, Nordisk Forlag, Leipzig: Otto Harrassowitz, p. 53).

57 Eckert. Kurland unter dem Einfluss des Merkantilismus, p. 167-168; Juškevičs. Hercoga Jēkaba laikmets Kurzemē, pp. 205, 208; Bundurs. Senās latvju kolonijas Gambija Tabago, p. 10. Mattiesen. Die Kolonial- und Überseepolitik der kurländischen Herzöge, pp. $58-74$.

Ibid., pp. 60-65.

Marek Arpad Kowalski (2005). Kolonie Rzeczypospolitej. Warszawa: Bellona, pp. 101-102. The author apparently linked the King of Poland to the history of negotiations of 1647-1648 between Duke Jacob and Gdańsk banker Israel Jasky, who was the subject of the Polish Crown, on the creation of a joint colonial company. However, the name of Władysław IV does not appear in these negotiations (Mattiesen. Die Kolonial- und Überseepolitik der kurländischen Herzöge, pp. 82-85).

${ }^{61}$ Kowalski. Kolonie Rzeczypospolitej, pp. 109-110. John II Casimir was linked fictitiously to the negotiations of 1651-1654 between Jacob and Pope Innocent X (was Pope in 1644-1655) (Theodor Schiemann (1886). Herzog Jacobs von Kurland Beziehungen zur päpstlichen Curie. In: Historische Darstellungen und Archivalische Studien. Beiträge zur Baltischen Geschichte von Dr. Theodor Schiemann. Hamburg: Gebr. Behre's Verlag, Mitau: 
E. Behre's Verlag, pp. 229-241, here pp. 234-240; Mattiesen. Die Kolonialund Überseepolitik der kurländischen Herzöge, pp. 371-376).

Diederichs. Herzog Jacobs von Kurland Kolonien, pp. 14-15; Eckert. Kurland unter dem Einfluss des Merkantilismus, pp. 167-168.

63 These are the good luck message to Jacob with his colonial enterprises from the aforesaid banker Jasky (1649) and the beginning of the productive cooperation between Duke and the Amsterdam merchant Henry Momber in the field of maritime and colonial affairs (1650) (see Mattiesen. Die Kolonial- und Überseepolitik der kurländischen Herzöge, pp. 82-85, 95-109; Briefe von Henri Momber bestellten Factoren in Amsterdam an den Herzog in Schiffs- u. Handelsangelegenheiten [in German and Dutch], 1650-1653. LNA-LVVA, 554-1-709).

64 Sewigh. Eine kurländische Colonie, p. 39; Seraphim. Mißlungene Seefahrten, p. 79; Juškevičs. Hercoga Jēkaba laikmets Kurzemē, pp. 259-261; Mattiesen. Die Kolonial- und Überseepolitik der kurländischen Herzöge, pp. 985-990; W. R. Menkman (1940). Tobago. Een bijdrage tot de geschiedenis der Nederlandsche kolonisatie in tropisch Amerika. Part 5. De WestIndische Gids, 22, pp. 97-110, here pp. 109-110; Alexander V. Berkis (1969). The History of the Duchy of Courland (1561-1795). Towson (Maryland): The Paul M. Harrod Company, pp. 215-217, 224; Andersons. Senie kurzemnieki Amerikā un Tobāgo kolonizācija, pp. 298-307; Bundurs. Senās latvju kolonijas Gambija Tabago, p. 20.

65 Klopmann. Abrégé de l'Histoire de Tabago. West-Indische Gids, pp. 193216.

66 Juškevičs. Hercoga Jēkaba laikmets Kurzemē, p. 261; Mattiesen. Die Kolonial- und Überseepolitik der kurländischen Herzöge, pp. 989-990; Berkis. The History of the Duchy of Courland, p. 224; Andersons. Senie kurzemnieki Amerikā un Tobāgo kolonizācija, p. 306; Bundurs. Senās latvju kolonijas Gambija Tabago, p. 20.

67 "[...] eventualiter succedirender Herzog [...]" (Carl von Rummel (comp.) (1851). Die Quellen des Curländischen Landrechts. Bd. 2. Curländischen Landtags- und Conferential-Schlüsse von 1618 bis 1759. Dorpat: F. Kluge, p. 490).

68 "Les États convoquèrent même une diéte a la fin de juin 1726. [...] et sélirent Maurice Comte de Saxe, Duc de Courlande et de Semigalle, titre qu'il a toujours conserve" (Ewald von Klopmann's essay on the history of the Island of Tobago [in French], 15.03.1796, 01.01.1798. RGADA, 11-1570, pp. 17, 38. v - 39; Klopmann. Abrégé de l'Histoire de Tabago. WestIndische Gids, p. 205).

69 Klopmann. Abrégé de l'Histoire de Tabago. West-Indische Gids, pp. 205206: "A peine fut-il élu Duc de Courlande, qu'il songea d'abord à envoyer des colonistes à Tobago, pour y faire de nouvelles plantations à l'instar des 
précédents ducs et considérant cette île comme appartenant au duché de Courlande. Il en nomma gouverneur Mr. de Brincken, gentilhome Courlandais et engagea plusieurs personnes à l'accompagner, dans des conditions assez avantageuses. Il compta beaucoup, comme de raison, sur le Roi de Pologne et sur la France pour être soutenu dans cette entreprise, mais l'influence de la Cour de Russie toujours prépondérante et salutaire à la Courlande contrebalança bientôt comme de juste droit, le parti de Maurice, qui fut obligé de quitter la Courlande et d'abandonner son vaste projet sur l'île de Tobago".

70 Although the last name of "Baron Klopmann" is used in the original document in the third person and without mentioning the first name, there is no doubt that it is precisely about Ewald von Klopmann: to talk about himself in the third person is a characteristic feature of his historical and autobiographical works (see Ewald von Klopmanns Aufzeichnungen über sein Leben (1893). Issued by Heinrich Diederichs in Baltische Monatsschrift, 35 (40), pp. 108-131, here p. 110).

71 Klopmann. Abrégé de l'Histoire de Tabago. West-Indische Gids, p. 206: "Le Duc Ernst Jean témoigna le désir de relever ses prétentions sur lîle de Tobago, à titre d'alleu acquis de la famille ducale de Kettler; il avait même destiné son gentilhomme de Chambre, le Baron Klopmann à être envoyé à Londres: Klopman y avait demeuré 6 ans, après avoir été attaché à l'Ambassade du Chevalier Williams en Russie afin de solliciter le Roi, en réclamant sa protection et de renouveler l'ancien Traité, fait par le Duc Jacques de Courlande et le Roi Charles II d'Angleterre [...] La mort du Duc Ernst Jean de Biron interrompit ses projets. Il est évident et hors de toute contestation possible, que l'île de Tabago a été acquise par le Duc Jacques, qu'elle a passé comme alleu par succession d'heritage dans la familie ducale de Kettler, et qu'enfin le Duc Ernst Jean en fit l'acquisition par un accommodement avec les héritiers de cette famille, comme de tous les alleux lui appartenant, en rachetant toutes les terres allodiales engagées par les Ducs précedénts, pour une somme très considérable, condition stipulée alors par le Roi et la République de Pologne, avant l'investiture du Duc".

72 Ewald von Klopmanns Aufzeichnungen über sein Leben, p. 110.

73 Sidney Lee (ed.) (1900). Williams, Sir Charles Hanbury (1708-1759). In: Dictionary of National Biography. Vol. 61, London: Smith, Elder, \& Co., pp. 379-383, here p. 381.

74 Petr Karlovich Shchebal'skii (1866). Vopros o Kurliandskom gertsogstve pri imperatore Petre III. Russkii arkhiv, 3, pp. 283-303, here p. 285; Imants Lancmanis, Ieva Lancmane, Valda Vilīte, Jānis Baltiņš (1993). Ernst Johann Biron 1690-1990. Katalog der Ausstellung im Schloß Rundāle / Ruhental. Rìga: Rīgas Paraugtipogrāfija, pp. 29-44.

75 Ewald von Klopmanns Aufzeichnungen über sein Leben, pp. 116-120. 
76 Alexander Chalmers (ed.) (1817). Williams (Charles Hanbury). In: The General Biographical Dictionary. Vol. 32, London: Printed for J. Nichols, pp. 99-103, here p. 102; Lee (ed.). Williams, Sir Charles Hanbury. Dictionary of National Biography, p. 381. An additional evidence of these chronological frames is George Townshend, 1st Marquess Townshend (17241807) mentioned in Klopmann's autobiography. The latter wanted to join the military expedition of the British against Quebec headed by Townshend, but due to illness he could not do it. Townshend sailed to North America in February 1759 (Ewald von Klopmanns Aufzeichnungen über sein Leben, pp. 120-121; Sidney Lee (ed.) (1899). Townshend, George. In: Dictionary of National Biography. Vol. 57, London: Smith, Elder, \& Co., pp. 123-126, here p. 123). Ibid., pp. 121-122.

Ibid., pp. 122-129. See also Johann Friedrich von Recke, Karl Eduard Napiersky (eds.) (1829). Von Klopmann (Ewald). In: Allgemeines Schriftstellerund Gelehrten-Lexikon der Provinzen Livland, Esthland und Kurland. Vol. 2, Mitau: Johann Friedrich Steffenhagen und Sohn, pp. 453-456, here pp. $454-455$.

80 Ewald von Klopmanns Aufzeichnungen über sein Leben, p. 113.

81 Ewald von Klopmann's essay on the history of the Island of Tobago [in French], 15.03.1796, 01.01.1798. RGADA, 11-1-570. Ibid., p. 1.

Ibid., pp. 18-19. v.

Ibid., pp. 20-20. v: “[...] et ses alleux en Courlande dont l'Isle de Tabago, devoluë par heritage et accommodement fait entre son père, et les héritiers de la famille Ducale de Kettler, fait parti, sans contredection quelconque. Partant de ces principes, comme d'un Axiome, fondé dans les droits inalterabler de la nature et des gens, il seroit fort aisé à prouver les justes et indubitable Tîtres de Sa Majeste Impériale de touter les Russies, sur la dite Isle de Tabago, comme un Alleu, appartenant an dernier Duc de Courlande, acquis par un achât formel, \& resignation solemnelle. Que Cathérine II., la Legislatrice, la Bienfaitrice de tans de millions dans Ses vastes Empires, daigne jetter un jour un régard sur l'Isle de Tabago, l'ancien patrimoine des Ducs de Courlande!”.

Ibid., p. 27: "Sire! Votre Majesté Imperialé ayant desire d’avoir l'histoire de l'isle de Tabago, jose en presenter à Ses pièds un abregè [...]". Ewald von Klopmanns Aufzeichnungen über sein Leben, p. 455.

Mattiesen. Die Kolonial- und Überseepolitik der kurländischen Herzöge, p. XXXVII; J[ean Chrétien Joseph] Kleyntjens S. J. (1949). De koerlandse kolonisatiepogingen op Tobago. West-Indische Gids, 30, pp. 194-195. 
89 Recke, Napiersky (eds.). Von Klopmann (Ewald). Allgemeines Schriftstellerund Gelehrten-Lexikon, p. 455; Ewald von Klopmanns Aufzeichnungen über sein Leben, pp. 130-131; Mattiesen. Die Kolonial- und Überseepolitik der kurländischen Herzöge, p. 436; Kleyntjens. De koerlandse kolonisatiepogingen op Tobago, p. 194.

90 Heinrikhs Strods (1993). Kurliandskii vopros v XVIII veke. Part 2, Riga: Latviiskii universitet, pp. 29-45, 60-61.

91 Letter from the merchant from Riga Friedrich Thiringk to the Duke Ernst Johann von Biron [in German], 14.11.1763. LNA-LVVA, 554-3-388, pp. 8-9. v: "Durchlauchtigster Hertzog, Gnädigster Fürst und Herr. Es hat der Londenschen Kauffmann Atkins von der Familie der seeligen Capitaine John Poyntz und compagnie, an welche der Weyland durchlauchtigste Hertzog Jacobus höchst seeligsten Andenkens mittelst Vergleichs puncten de dato den 20-ten September 1681 und ratification de dato Mitau den 24-ten October 1681 Einhundert und zwanzig tausend Acker Land in der Insul Tobago zugestanden haben den Auftrag bekommen, derselben Familie die in der angefügten Specification benennte documenta in copiis fidimatis aus Ew. Hochfürstl. durchl. Archiv zu dem Ende zu besorgen, damit mehr gedachte Familie diese documenta ehesten erhalte, und dadurch verhindern könne, daß derselben District Land von der Cron Engeland nicht an andere vergeben werde. Da nun Eingangs gedachter Atkins mich ersucht, Ihme zu diesen documenten zu verhelffen. So bitte Ew. Hochfürstl. durchl. demüthigst, gnädigsten befehl ergehen zu laßen, daß mir diese documenta aus höchst deroselben Archiv in copiis fidimatis gegen die gebühr ausgefertiget werden sollen. Ich verharre in tieffster devotion. Ew. Hochfürstl. durchl. Meines Gnädigsten Fürsten und Herren. demüthigster Friedrich Thiringk bürger und kauffmann zu Riga. Specification von Schrifften von welchen vidimirte Copeyen nach Engeland verlangst werden: 1-mo. Von Einer Vollmacht Sr. Hochfürstl. durchl. des Hertzoges Jacobus, unter deroselben Hand und Siegel datirt Mitau den 3-ten Julij 1681 und gegeben an den Hochfürstl. Residenten in London Abraham Marin um wegen Cultivirung der Insul Tobago ein Contract zu schließen. 2-do. Von Vergleichs puncten datirt den 20-ten Septembris 1681 worinnen und wodurch Sr. Hochfürstl. durchl. durch dero Residenten an den Capitaine John Poyntz er Compagnie zugestanden haben Einhundert und zwanzig tausend Acker Land in der Insul Tobago, bey welchen Vergleichs puncten. 3-tio. Die Ratification Sr. Hochfürstl. durchl. angehänget ist, unter dero Hand und Siegel datirt Mitau den 24-ten October 1681. Prod. die 14-te Novbr. Ao 1763. Hochfürstl. Kantzeley".

92 The definitive Treaty of Peace and Friendship between his Britannick Majesty, the Most Christian King, and the King of Spain. Concluded at Paris the $10^{\text {th }}$ day of February, 1763. To which the King of Portugal acceded on 
the same day. Article IX. Available at: http://avalon.law.yale.edu/18th_century/paris763.asp (accessed 17.01.2018).

Erklärung des Herzogs Ferdinand v. Kurland wegen der Insel Tabago [in German], 08.09.1731, 03.10.1731. The Hessian State Archives in Marburg (Hessisches Staatsarchiv Marburg), Bestand 4f - Staaten K - Nr. Kurland 123.

94 Fowler. A Summary Account, p. 22.

95 Enn Küng (2015). Die Gefangenschaft Herzog Jakobs von Kurland in Ivangorod 1659-1660. Forschungen zur baltischen Geschichte, 10, pp. 69-91. Edgar Anderson (1962). Die kurländische Kolonie Tobago, I. Baltische Hefte, 8 (3), pp. 129-155, here p. 149.

97 Andersons. Senie kurzemnieki Amerikā un Tobāgo kolonizācija, pp. 309321.

98 Diederichs. Herzog Jacobs von Kurland Kolonien, pp. 47-50.

The text of this agreement was often published. For example, see Klopmann. Abrégé de l'Histoire de Tabago. West-Indische Gids, pp. 209-210.

${ }^{100}$ Ibid., p. 203.

${ }^{101}$ Arguments in favour of this view see A[leh] I[haravich] Yeustratsyeu (2017). "Obeshchaem ekhat' v Norvegiiu": svedeniia odnogo trudovogo kontrakta o territorial'noi mobil'nosti "rusakov" v XVII v. Studia Historica Europae Orientalis, 10, pp. 127-148, here pp. 135-137.

${ }^{102}$ For example, see Kołodziejczyk. Czy Rzeczpospolita miała kolonie w Afryce i Ameryce? [Did the Polish-Lithuanian Commonwealth have colonies in Africa and America?]; Armin M. Brandt (1999). Kurlands Kolonien. Geschichte mit Pfiff, 7, p. 21; Tomasz Cukiernik (2008). Kolonialna Kurlandia [Colonial Courland]. Available at: http://tomaszcukiernik.pl/artykuly/ artykuly-historyczne/kolonialna-kurlandia/ (accessed 07.01.2018); Wojciech Kempa. Kolonialne marzenia [Colonial dreams]. Nowe Siemianowice, 19.12.2012, p. 6; Olbrychski. Tobago: zamorskie kresy Rzeczypospolitej [Tobago: the overseas borderlands of the Polish-Lithuanian Commonwealth]; Pogorelyi. S privetom iz Afriki; Marcin Dobrowolski (2016). Polskie imperium kolonialne [The Polish colonial empire]. Available at: https:// www.pb.pl/polskie-imperium-kolonialne-835760 (accessed 07.01.2018); Dobrovol'skii. V Afrike i Amerike; Kariby, Afrika i rom. Istoriia kolonii VKL v XVII-om veke; Kurländische Kolonialgeschichte (From Wikipedia, the free encyclopedia). Available at: https://de.wikipedia.org/wiki/ Kurl\%C3\%A4ndische_Kolonialgeschichte (accessed 07.01.2018) (compare also versions in other languages). 


\section{KURZEMES HERCOGISTES KOLONIĀLĀS POLITIKAS VĒSTURES DATĒJUMi}

\section{Oḷegs Jevstratjevs}

Mg. hist., Republikāniskais augstākās izglītības institūts (Minska, Baltkrievija), Baltkrievijas vēstures un kultūras mantojuma katedras vecākais pasniedzējs.

Zinātniskās intereses: Baltijas regiona vēsture agrīnajos jaunajos laikos, Kurzemes hercogistes vēsture, Eiropas koloniālisma vēsture.

Rakstā tiek analizētas historiogrāfijā sastopamās Kurzemes hercogistes koloniālās politikas periodizācijas versijas un to rašanās iemesli. Autors secina, ka lielākajai daḷai pieṇēmumu par Kurzemes hercogistes koloniālās politikas sākuma un beigu datējumu pašlaik apzinātajos vēstures avotos nav atrodams pamatojums. Tieši šie pieņēmumi (versijas) Kurzemes hercogistes koloniālajai politikai veltītajos vēstures pētījumos un populārzinātniskajā literatūrā ir veicinājuši šis tematikas mitologizāciju.

Atslēgas vārdi: Kurzemes hercogiste, koloniālā politika, datējums.

\section{Kopsavilkums}

Kurzemes koloniālās politikas vēsturei, it īpaši Tobāgo salas kolonizācijai, ir svarīga loma latviešu vēsturiskajā atmiņā. Tomēr šì tematika ļoti lielā mērā ir dažādiem mītiem apvīta. Īpaši tas attiecas uz notikumu datējumu. Historiogrāfijā ir sastopamas vairākas pretrunīgas versijas par Kurzemes hercogistes koloniālās politikas sākumu. Par to, kad Kurzemes hercogiste ir iegādājusies Tobāgo salu un ir aizsākta tās kolonizācija, ir atrodami dažādi gadskaiț̣i: 1610., 1634., 1637., 1638., 1639., 1640., 1642. gads, 17. gadsimta 40. gadu vidus vai arī angḷu karaḷa Čārlza I valdīšanas laiks (1625-1649). Šie gadskaitl̦i nav atrodami ticamos vēstures avotos, jo tie ir ņemti no vēlāku laiku ziṇojumiem, ko snieguši gan britu piedzīvojumu meklētāji, proti, Džons Skots (John Scott) 1667. gadā un Džons Points (John Poyntz) 1699. gadā, gan Kurzemes diplomāti - Karls Johans fon Blombergs (Karl Johann von Blomberg) 1700. gadā un Johans Kristofs Pretoriuss (Johann Christoph Praetorius) 1727. gadā. Šķiet, daḷa versiju par šo notikumu datējumu ir 19.-20. gadsimta vēsturnieku izdomājums. Šie pētnieki vēlējās uzsvērt Kurzemes klātbūtnes vēsturi Tobāgo salā, attiecīgi viṇu ziṇojumus nevar pieskaitīt pie uzticamiem avotiem. Balstoties uz ticamiem avotiem, Kurzemes kolonijas dibināšana Tobāgo salā datējama ar 1654. gadu, bet Svētā Andreja salā Gambijas upes grīvā - 
ar 1651. gadu. Tomēr kurzemnieku pirmās aizjūras darbības pēdas ir konstatējamas jau pirms tam. Spriežot pēc dažādu pētnieku norādītajiem datumiem, proti, 1627., 1629., 1630., 1642., 1643., 1645., 1647., 1649. , 1650., 1653. gads, pirmie reālie mēginājumi attīstìt koloniālo tirdzniecību un dibināt aizjūras kolonijas bija 1645. gadā - hercoga Jēkaba Ketlera valdīšanas laikā (1642-1681). Šajā gadā ir dokumentāli fiksēts, ka hercogs Jēkabs piedalījies trīspusējā tirdzniecībā starp Eiropu, Gvineju un Vestindiju un nosūtījis arī pirmo ekspedīciju uz Gvineju.

Attiecībā uz Kurzemes koloniālās politikas beigu datējumu historiogrāfijas vispārpieṇemtā versija ir tā, ka šī politika turpinājās līdz pat Kurzemes hercogistes pievienošanai Krievijas impērijai 1795. gadā. Tomēr tam nav rodams apstiprinājums ticamos vēstures avotos. Šķiet, šì atziņa radusies, iepazīstoties ar 1795. vai 1796. gadā sarakstīto Kurzemes barona Evalda fon Klopmana (Ewald von Klopmann, 1734-1804) manuskriptu, kurā ir informācija par Tobāgo salu. Autors, vēlēdamies būt lojāls pret jaunajiem kungiem un cerēdams uz zināmu atlīdzību, ir devis mājienu imperatorei Katrīnai II un viņas pēcnācējam Pāvilam I, ka Krievijai ir iemesls pretendēt uz Tobāgo salu, jo tā var tikt mantota no pēdējā Kurzemes hercoga Pētera Bīrona (valdīšanas laiks - 1769-1795). Tomēr Klopmana apgalvojumam, ka Ketlera dzimtas pēcteči piedalījušies cīṇā par šo salu, nav rodams apstiprinājums citos avotos. Minētajā manuskriptā ir daudz log̣isku un hronologisku pretrunu, un tā rašanos var izskaidrot tikai ar autora savtīgiem nolūkiem, tādēḷ tas nevar tikt uzskatīts par uzticamu. Pēdējie uzticamie avoti par šo problemātiku datēti ar 1731. gadu un ir saistīti ar trimdā dzīvojošā hercoga Ferdinanda Ketlera (1655-1737) neveiksmīgajiem mēǵginājumiem pārdot Tobāgo salu savam brāḷadēlam Zviedrijas karalim Frederikam I (valdīšanas laiks - 17201751).

Balstoties uz vēstures avotiem, var secināt ka Kurzemes hercogistes koloniālās politikas vēsture datējama ar laika posmu no 1645 . līdz 1731. gadam. Visas citas hipotēzes ir tikai vēlākā perioda fikcija. 